\title{
Current Overview of Carbon Fiber: Toward Green Sustainable Raw Materials
}

\begin{abstract}
Yongjian $\mathrm{Xu},{ }^{\mathrm{a}}, *$ Yan Liu, ${ }^{\mathrm{a}}$ Shenglin Chen, ${ }^{\mathrm{a}}$ and Yonghao $\mathrm{Ni}^{\mathrm{b}}$
Lignin, as a potential precursor of carbon fiber, has the characteristics of abundant reserves, renewable and high carbon content, and its application in the preparation of carbon fibers has substantial cost advantages if some important processing and quality hurdles can be overcome. This paper reviews the preparation process of lignin-based carbon fibers, and moreover, describes the characteristics of carbon fiber prepared by different precursors compared with the presently used precursors. Three preparation methods for lignin-based carbon fibers are introduced: melt spinning, solution spinning, and electrospinning. The applicability, advantages, and disadvantages of the three preparation methods are analyzed from the aspects of process conditions and performance characteristics. Possible directions for future research are considered, with the goal of providing a reference for further study of lignin-based carbon fibers.
\end{abstract}

Keywords: Lignin; Carbon fiber; Preparation method; Spinning

Contact information: a: Shaanxi Provincial Key Laboratory of Papermaking Technology and Specialty Paper Development, Key Laboratory of Paper Based Functional Materials, China National Light Industry, National Demonstration Center for Experimental Light Chemistry Engineering Education, Shaanxi University of Science \& Technology, Xi'an, 710021, China; b: Chemical Engineering, University of New Brunswick, Fredericton, New Brunswick, Canada; *Corresponding author: xuyongjian@sust.edu.cn

\section{INTRODUCTION}

Lignin is an abundant natural resource that has an annual production of about 600 billion tons, second only to cellulose (Qian et al. 2018). Lignin, cellulose, and hemicellulose constitute the three major components of a plant cell wall (Fechter and Heinze 2019; Tian et al. 2019). Currently, cellulose, and hemicellulose are widely used in industry such as papermaking, sugar, and biofuels (Horhammer et al. 2011; Mikkonen et al. 2019; Singh 2019) (Fig. 1). As a by-product of wood hydrolysate and the paper industry, lignin is present in solution as black liquor (accounting for more than $30 \%$ of black liquor solids). Most black liquor is sent to a recovery boiler, where the lignin is incinerated and converted to steam energy, with the recovery of pulping chemicals. The incineration of the lignin to generate steam is a low-value application. It follows that the potential value of lignin as a source for other products is not being fully realized (Lauwaert et al. 2019). It is reported that more than 50 megatons of industrial lignin are produced worldwide per year, but only $2 \%$ of the lignin is commercialized for valueadded purposes (Qian et al. 2018). Most lignin is simply used as cheap fuel for combustion, which causes waste of resources, and the high value utilization of macromolecules is still not realized (Liu et al. 2017). Therefore, development of relevant technologies for high-value utilization of lignin is of fundamental and practical interest (Qian et al. 2014; Zhang et al. 2017). 
Carbon fibers are excellent materials with many potential applications and have received growing interest due to their fascinating features such as unique thermal properties, high tensile strength, and so on (Gao et al. 2015). Currently, more than $90 \%$ of commercially marketed carbon fibers in the world are made from polyacrylonitrile (PAN), a non-renewable petroleum-based material (Zhang et al. 2014; Zhang et al. 2019). Moreover, the price of PAN precursors accounts for $50 \%$ of the manufactured cost of carbon fibers (Baker and Rials 2013), making carbon fiber a luxury product. Therefore, finding a renewable environment-friendly precursor (such as lignin) of carbon fiber used in low-value applications has been of great interest in recent years.

Lignin, as a bio-derived alternative, has received growing interest in the production of carbon fiber due to high carbon content of $50 \%$ to $71 \%$ as well as its availability in large quantities at low cost (Li et al. 2017). Although it is currently challenging to replace PAN-based carbon fibers in demanding applications, lignin-based carbon fibers can be considered for general applications. For instance, the properties of lignin-based carbon fibers may be suitable for applications requiring medium mechanical properties, low density, high temperature resistance, low thermal expansion, and thermal conductivity. For such applications, the use of lignin-based carbon fibers may be favored because of their low cost and green reproducibility.

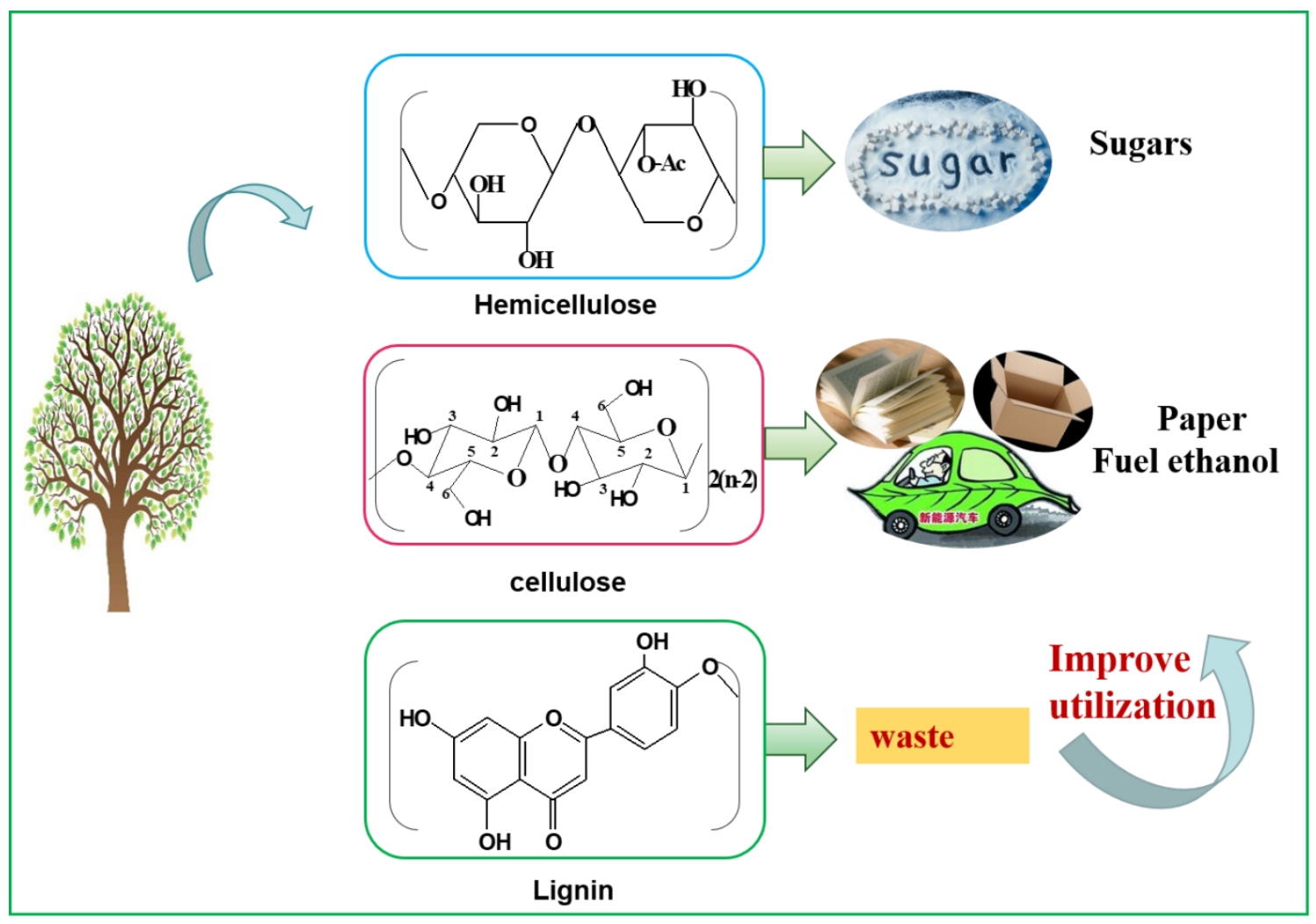

Fig. 1. Applications of three components of plant cell wall

This paper reviews the preparation process of lignin-based carbon fibers and describes the difference between lignin and other precursor raw materials (such as PAN, pitch, and viscose fiber). Three spinning methods for lignin-based carbon fibers: melt spinning, solution spinning, and electrospinning, are highlighted. Moreover, the 
applicability, advantages, and disadvantages of the three preparation methods are discussed. This paper aims to promote the development of lignin-based carbon fibers.

\section{LIGNIN}

Lignin was first discovered by French agronomist P. Payen in 1838. Later, F. Schulze, a German, separated the substance and called it "lignin", which was derived from the Latin "lignum," meaning wood (Souto et al. 2018).

Lignin exists in cell wall as a filler and binder, which plays an important role in plant growth. It can strengthen the cell wall by bonding the adjacent cells together, giving the cells and the plant stem great mechanical strength (Lebo, Jr. et al. 2000). The content of lignin in lignified plants varies by biomass species. In softwood, lignin content is $25 \%$ to $35 \%$, whereas the content is $20 \%$ to $25 \%$ in hardwood. Gramineae plants have lower lignin content, generally $15 \%$ to $25 \%$.

\section{Physical Properties}

Unseparated lignin in plant cells is white or nearly colorless, with a molecular weight of several hundred thousand $\mathrm{g} / \mathrm{mole}$ and insoluble in any solvent. However, the separated lignin has a much lower molecular weight due to degradation, generally ranging from a few hundred to tens of thousands of $\mathrm{g} / \mathrm{mole}$. It can be divided into soluble lignin and insoluble lignin.

Lignin is a complex polymer produced by free radical coupling reactions in plant cell walls. Their monomer components and the polymer itself are optically active, that is, they are chiral. Lignin has long been considered to have no optical activity. This is because it is derived from chiral monomers, which seem to be the result of chemical reactions not controlled by enzymes. But there does not seem to be any hard evidence to support that claim. In response to the problem that lignin's optical activity cannot be detected, Ralph et al. (1999) proposed that when lignin is being synthesized by plants, there is no direct (regional or three-dimensional) control over the exact process of freeradical coupling events.

Lignin is an amorphous thermoplastic polymer with no stable melting point, exhibiting a high glass transition temperature (Vural et al. 2018). Below the glass transition temperature, lignin behaves as a glassy solid. When the temperature is higher than the glass transition point, the molecular chain segments are able to move, resulting in lignin softening and undergoing viscous flow in response to stress. The ability of lignin to cool without forming a crystalline phase, i.e. vitrification, is not common in natural macromolecular resources. Lignin exhibits both thermoplastic and vitrification properties. In this respect, lignin resembles certain biobased plastics that are synthesized by microbial fermentation. The thermoplastic and vitrification properties of lignin are not shared by other natural macromolecules such as starch and cellulose. The vitrification temperature varies with species, separation method, molecular weight, and water content (Perez et al. 2011; Duval et al. 2013; Zhou et al. 2016). The softening temperature of absolutely dried lignin is between 127 to $129{ }^{\circ} \mathrm{C}$. Moreover, the softening points obviously decrease with the increase of moisture content of lignin samples. For example, the softening temperature of periodate lignin decreased from $193{ }^{\circ} \mathrm{C}$ to $93{ }^{\circ} \mathrm{C}$ when the moisture content in the sample was increased from 0 to $27.1 \%$ (Jafarpour et al. 2009). 
The mobility of water molecules affects the softening temperature of lignin, indicating that water is a plasticizer for lignin.

\section{Chemical Structure and Properties}

Lignin protects plant cells from biological and chemical damage (Terashima 2013). Covalent bonding between lignin and hemicellulose is known to exist. Whether lignin is chemically bonded to cellulose has not been determined. But the combination of lignin and carbohydrate is customarily referred to as the lignin-carbohydrate complex (LCC) (Fig. 2). Because of its complex combination with cellulose and hemicellulose, it is difficult to separate and identify it completely. The effective separation of lignin from cellulose and hemicellulose plays an important role in improving the utilization rate (Harfouche et al. 2010; Yu et al. 2016). Research on this issue has been conducted for centuries, and many separation methods have been discussed as far back as 105 A.D., when papermaking technology was invented in China. At that point the term "lignin" did not exist. In fact, the fundamental reason for the difficulty in separation lies in the complexity of the sequence of chemical components, the way it is connected, and the three-dimensional structure of lignin (Vicuna 2000; Liitia et al. 2003). These questions have aroused extensive interest among scientists. A variety of modern advanced characterization methods have been used to investigate the structure of lignin, and important progress has been made (Lindgren et al. 1974).

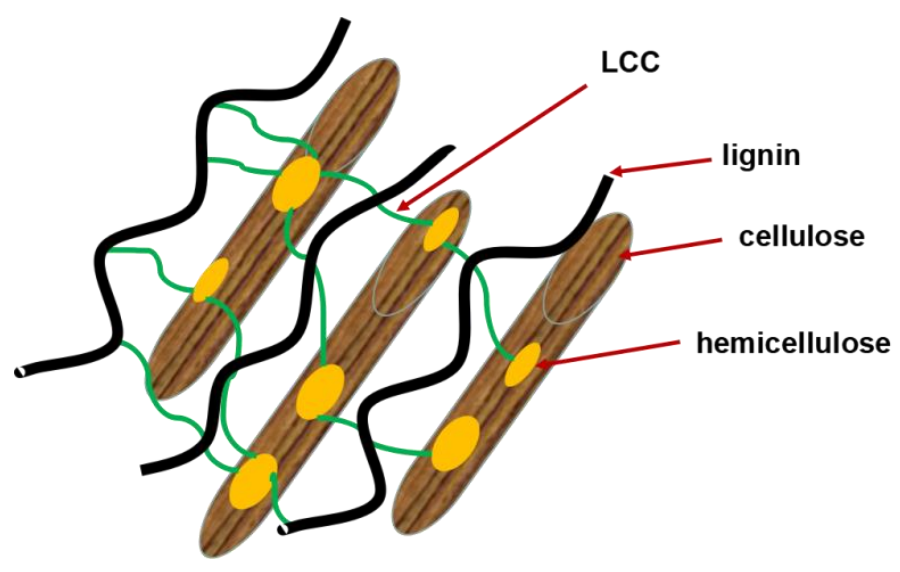

Fig. 2. The connection between lignin, cellulose, and hemicellulose

Phenol-propane units constitute the basic skeleton structure of lignin (Bolker and Brenner 1970), and the units are connected together by ether bonds and carbon-carbon bonds. Recent studies also have found ester bonds between lignin structural units (Li et al. 2018). The chemical structure of lignin varies with plant species, so the term "lignin" does not represent a single substance, but a group of substances with common properties in plants. 


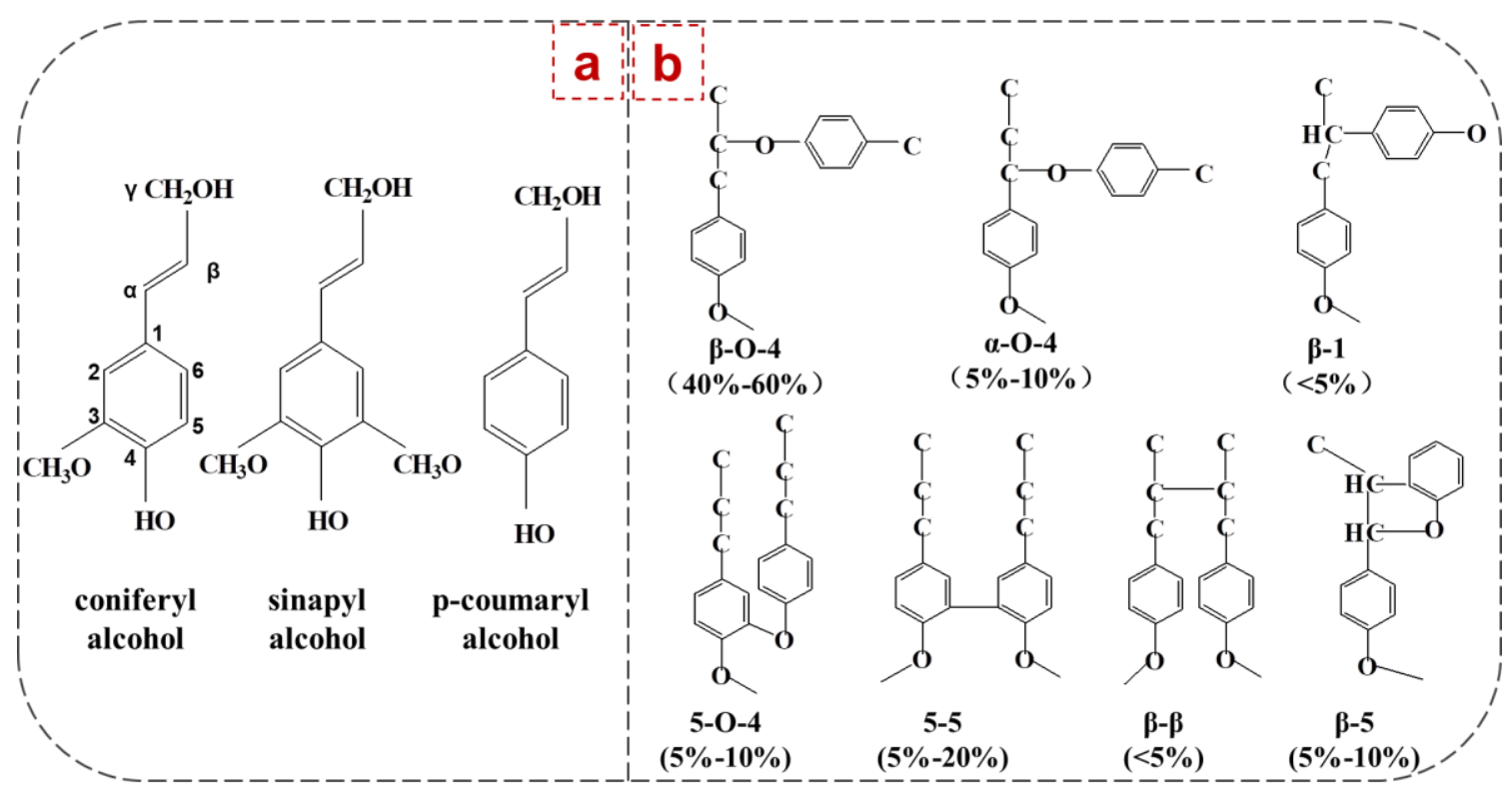

Fig. 3. (a) The basic structural units of lignin; (b) Main linkages between lignin structural units in woody plants

Table 1. Effect of Phenyl Propane Structure on Thermal Behavior

\begin{tabular}{|c|c|c|c|}
\hline $\mathrm{H}: \mathrm{G}: \mathrm{S}$ & Softwood Lignin & Hardwood Lignin & Herbaceous Lignin \\
\hline Thermostability & $\begin{array}{c}4: 95: 1 \\
\begin{array}{c}\text { Thermal instability, tends to } \\
\text { crosslink due to } \\
\text { imbalanced structure in } \mathrm{G} \\
\text { units }\end{array}\end{array}$ & $\begin{array}{c}\text { Chemically stable, less } \\
\text { likely to crosslink, tends to } \\
\text { fuse during stabilization }\end{array}$ & $\begin{array}{c}\text { Seldom used in } \\
\text { carbon fiber } \\
\text { production }\end{array}$ \\
\hline
\end{tabular}

Notes: H: hydroxyphenyl, G: guaiacyl, S: syringyl, the thermostability refer to high-temperature interactions

Studies have shown that lignin structure plays an important role in carbon fiber processing. Lignin is an amorphous aromatic polymer whose physicochemical and thermal properties depend on the biomass source and the lignin separation method. The phenol propane structure of lignin mainly consists of three monolignols, guaiacyl (G), syringyl $(\mathrm{S})$, and p-hydroxyphenyl $(\mathrm{H})$ units. They are results of three aromatic alcohol monolignols: coniferyl alcohol, syringyl alcohol, and coumaryl alcohol (Fig. 3a and Table 1) (Nawawi et al. 2016; Shioya et al. 2017). G units are mainly in softwood lignin, while $S$ units are mainly in hardwood lignin. The major units in gramineae are $\mathrm{G}$ and $\mathrm{S}$ units (Matsushita et al. 2007; Hirayama et al. 2019).

The phenol propane structural units of lignin are connected by ether bonds (mainly containing $\beta-\mathrm{O}-4, \alpha-\mathrm{O}-4$, and 5-O-4 linkages) and carbon-carbon bonds (consisting of $5-5, \beta-1, \beta-\beta$, and $\beta-5$ linkages), with the former generally accounting for $60 \%$ to $70 \%$ and the latter for $30 \%$ to $40 \%$ (Fig. 3b) (Beste and Buchanan 2012; Yang et al. 2016). Carbon-carbon bonds are highly stable when lignin degrades under the action of chemicals (Murakami and Ishida 2015). In addition, a small amount of ester bonds also exist, especially in grasses.

There are many active functional groups in the molecular structure of lignin, such as benzene ring, phenolic hydroxyl, alcohol hydroxyl, carbonyl, conjugate double bond, 
etc., which enable the lignin to undergo oxidation, reduction, hydrolysis, acid hydrolysis, sulfonation, alkylation, and other chemical reactions (Laurichesse and Averous 2014).

\section{Extracting Lignin from Plants}

There are two main methods to separate lignin. The first is to dissolve and remove other components in plants except lignin; such approaches generally separate and extract lignin as an insoluble component. The product prepared by this separation method is mainly hydrolyzed lignin (mainly kraft lignin (KL)). The second type of method dissolves lignin as a soluble component while other components (such as cellulose) are insoluble for the purpose of separation (Yuan et al. 2013). Such methods result in the production of alkali lignin (AL), lignin sulfonate (LS), organosolv lignin (OL), and steam explosion lignin (SEL), etc. These products are all obtained by the second separation method. Table 2 describes the characteristics of several industrial lignins.

Table 2. Types and Features of Lignin

\begin{tabular}{|c|c|c|}
\hline Type & Features & Application \\
\hline $\mathrm{AL}$ & $\begin{array}{l}\text { More hydroxyl groups, strong hydrogen bonding, } \\
\text { good or poor water solubility, depending on MW }\end{array}$ & $\begin{array}{l}\text { Synthesized polymers, } \\
\text { such as phenolic resin } \\
\text { adhesive }\end{array}$ \\
\hline $\mathrm{OL}$ & High purity, high solvent cost, and complex recovery & $\begin{array}{c}\text { Synthesized polymer, } \\
\text { such as lignin-based flocculant }\end{array}$ \\
\hline $\mathrm{KL}$ & $\begin{array}{l}\text { Compared with native lignin, phenolic hydroxyl } \\
\text { content is higher, methoxyl and alcoholic hydroxyl } \\
\text { content are lower, and purity is higher. }\end{array}$ & $\begin{array}{c}\text { Dispersant, } \\
\text { such as soil conditioner }\end{array}$ \\
\hline LS & $\begin{array}{c}\text { A surfactant amphiphilic polymer molecule whose } \\
\text { molecular structure is severely damaged during } \\
\text { pulping }\end{array}$ & $\begin{array}{l}\text { Polymeric dispersant, } \\
\text { such as cement water- } \\
\text { reducing agent }\end{array}$ \\
\hline SEL & $\begin{array}{l}\text { High requirements on equipment, high energy } \\
\text { consumption }\end{array}$ & $\begin{array}{c}\text { No commercialization at } \\
\text { present }\end{array}$ \\
\hline
\end{tabular}

\section{CARBON FIBERS}

\section{Development of Carbon Fiber}

Carbon fiber is a multifunctional linear carbon material that can have excellent mechanical properties, and its carbon content can reach $90 \%$ to $99 \%$ (Liu and Kumar 2012; Lee et al. 2014). It has good biocompatibility (Menini et al. 2017) and strong physiological adaptability (Usmani et al. 2016). Carbon fiber composite is a new implant material with good biocompatibility, stability, and reliability. Jenkins and coworkers (Jenkins et al. 1997; Jenkins and McKibbin 1980) demonstrated through animal experiments that carbon fiber implanted into living tissues has good biocompatibility and can stimulate the regeneration ability of surrounding tissues. The resulting collagen fibers function normally. Their preliminary clinical application has also achieved a good result.

The origins of carbon fiber date back to the 1860s. A British man named J. Swan used carbon filament to make light bulbs before the American T. A. Edison. The light bulb designed by J. Swan was not practical because it failed to solve the vacuum problem of the light bulb. However, he was the first to develop carbon silk and inspired the 
invention of synthetic fiber. Then, T. A. Edson successfully applied carbon filament to incandescent lamps in 1879 and made it practical (Souto et al. 2018).

\section{Carbon Fiber Raw Materials}

With the growth of carbon fiber demand, many precursors have been considered for the production of carbon fibers, such as polyacrylonitrile (Kim et al. 2014), asphalt (Lim et al. 2019), viscose fibers (Wang et al. 2016a), lignin (Meng et al. 2019), polyvinyl alcohol (Mercader et al. 2012), polyvinyl chloride (Liu et al. 2018a), and so on. Of these, only three main kinds of carbon fiber raw materials have been manufactured at commercial scale: PAN-carbon fiber (Liu et al. 2015), viscose-based carbon fiber (Gorina and Cheblakova 2016), and asphalt-based carbon fiber (Li et al. 2008).

The PAN-based carbon fibers with poor mechanical properties were first prepared in 1959 in Osaka, Japan, which promoted the development of the carbon fiber industry. Although the TORAY company of Japan has experienced many difficulties in producing high strength and high modulus carbon fiber, the company has achieved the leading levels of performance in this field in the world (Macia-Agullo et al. 2007; Jiang et al. 2009). The PAN-based carbon fibers are mainly produced in two steps. The first step is to produce polyacrylonitrile precursor, which mainly involves the polymerization of monomers and the preparation of spinning liquid, which is then spun further. This initial step is crucial in the production of carbon fiber because the quality of the precursor determines the performance of the carbon fiber. The second step is pre-oxidation and carbonization of the precursor. Figure 4 shows the preparation process (Yusof and Ismail 2012; Zhang et al. 2014).

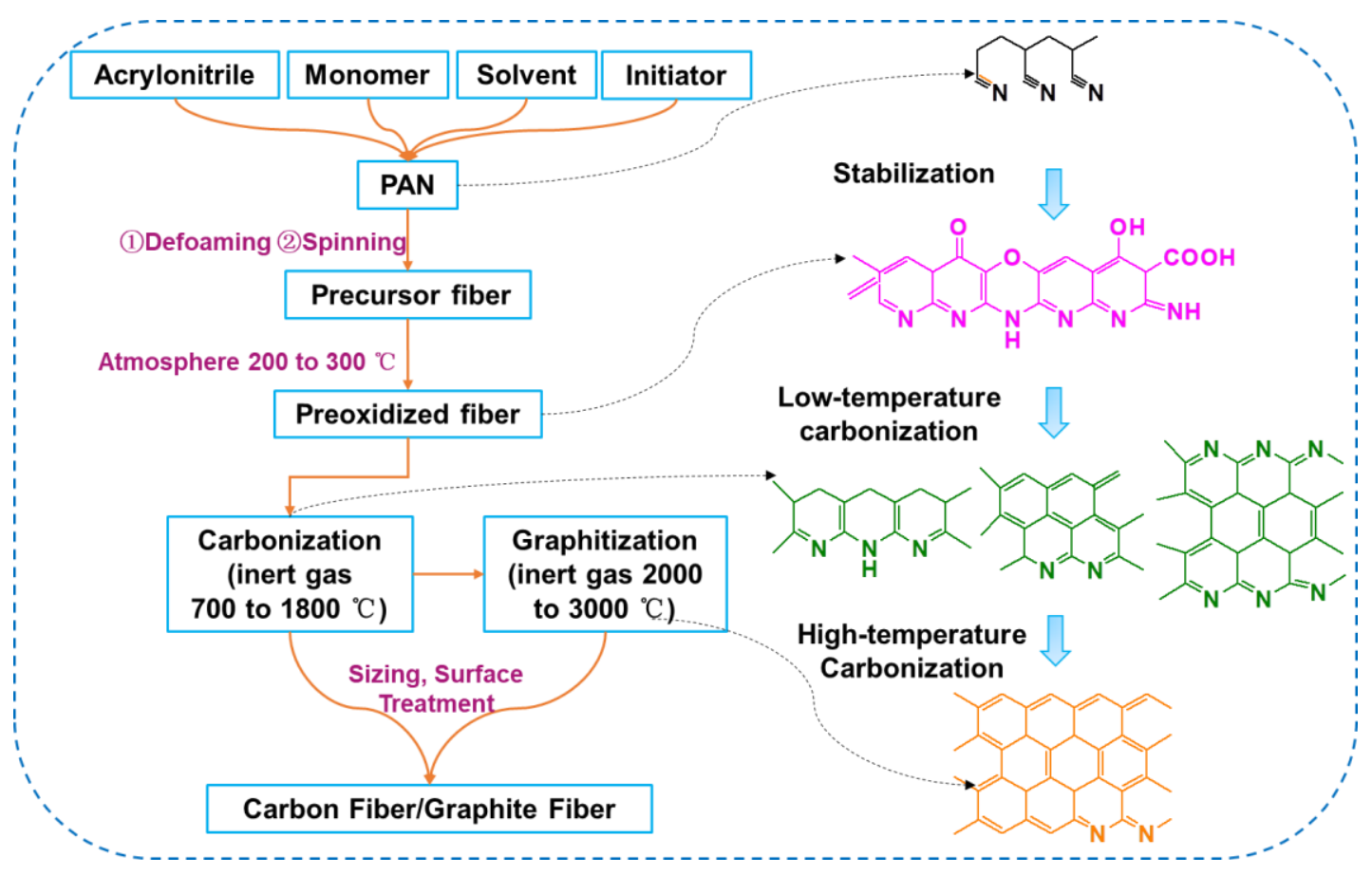

Fig. 4. PAN-based carbon fiber preparation processes

Pitch is second only to PAN as the raw material used to make carbon fiber (Matsumoto et al. 1993). There are two kinds of pitch-based carbon fibers. The first kind is general-purpose carbon fibers made from isotropic asphalt. Another type is high- 
performance carbon fibers made from mesophase pitch (Alway-Cooper et al. 2013; Yao et al. 2014). Pitch-based carbon fibers have higher thermal conductivity (Lee and Rhee 2019), better thermal expansion (Asano 2017), and more impact resistance (Meehan et al. 2010) than PAN-based carbon fibers.

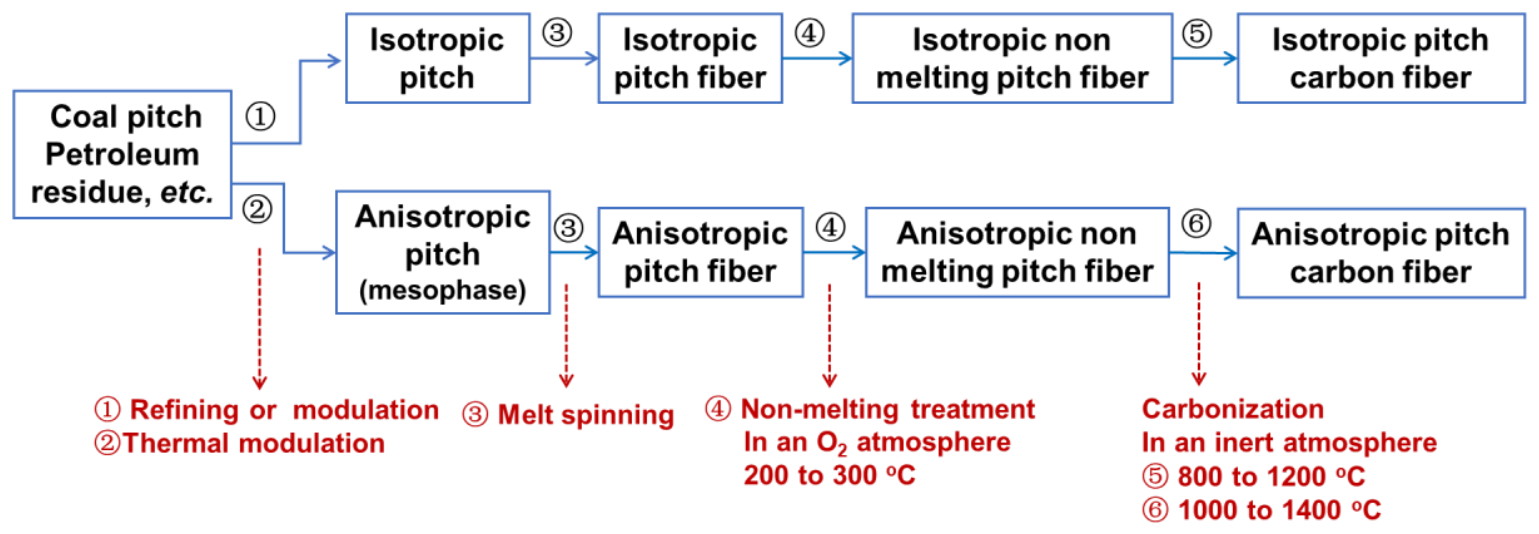

Fig. 5. Pitch-based carbon fiber preparation processes

Mesophase pitch is obtained by pretreatment of pitch or petroleum residue. Then the mesophase pitch is subjected to melt spinning, heat stabilized, and further carbonized to obtain asphaltene-based carbon fiber. It is worth noting that the obtained pitch-based carbon fiber varies with the pretreatment. The isotropic pitch-based carbon fiber is obtained through refining or modulation, while the anisotropic pitch-based carbon fiber is obtained through thermal modulation. The specific preparation conditions are shown in Fig. 5.

Viscose-based carbon fibers were invented in the 1950s. Until today, wood pulp and cotton pulp, mainly composed of cellulose, have been used in the production of viscose-based carbon fibers (Culica et al. 2019). The production process needs two more steps than that of PAN-based carbon fibers: washing and impregnating the catalyst, which undoubtedly increases the production cost (Paunonen et al. 2019). However, it has no impact on the irreplaceable position of viscose-based carbon fibers in the field of carbon fibers. In addition to thermal insulation and ablative resistance, viscose-based carbon fibers are also used as environmental and medical materials due to their welldeveloped pore structure and easy regulation ( $\mathrm{Su}$ and Wang 2007; Gorina and Cheblakova 2016).

Table 3. Comparisons of Four Precursor Fibers

\begin{tabular}{|c|c|c|c|c|c|}
\hline Type & Cost & $\begin{array}{c}\text { Preparation } \\
\text { Technology }\end{array}$ & $\begin{array}{c}\text { Carbonization Yield } \\
\text { (Raw Materials) }\end{array}$ & Performance & $\begin{array}{c}\text { Market } \\
\text { Share }\end{array}$ \\
\hline PAN & Highest & Simple & $40 \%$ & $\begin{array}{c}\text { High tensile } \\
\text { strength }(9.03 \mathrm{GPa})\end{array}$ & $>90 \%$ \\
\hline Pitch & Low & Complex & 85 to $90 \%$ & $\begin{array}{c}\text { Highest modulus } \\
\text { (930 GPa), high } \\
\text { thermal conductivity }\end{array}$ & $7 \%$ \\
\hline Viscose & Higher & $\begin{array}{c}\text { Complex } \\
\text { (need catalysis) }\end{array}$ & $30 \%$ & $\begin{array}{c}\text { Blation resistance, } \\
\text { heat insulation }\end{array}$ & $<1 \%$ \\
\hline Lignin & $\begin{array}{c}\text { Low, } \\
\text { renewable }\end{array}$ & Simple & 40 to $50 \%$ & $\begin{array}{c}\text { High specific } \\
\text { capacitance }\end{array}$ & - \\
\hline
\end{tabular}


The PAN and pitch precursors are derived from petroleum-based resources (Rhee et al. 2017), while carbon fibers from viscose have a high cost and a low yield (Su and Wang 2007; Paunonen et al. 2019). Table 3 summarizes the characteristics of four different classes of precursor fibers. With the depletion of fossil fuel resources and the aggravation of environmental pollution, it is urgent to find renewable environmentfriendly resources. Lignin, as a kind of abundant renewable resource second only to cellulose, has attracted increased attention in this regard.

\section{Applications of Carbon Fiber}

Carbon fiber, when well prepared, has many excellent properties that no other material can surpass, such as high strength, high modulus, low density, high temperature resistance, corrosion resistance, and other excellent functions (Frank et al. 2012). In addition, carbon fiber materials have a small thermal expansion coefficient, a good dimensional stability, and a strong adaptability to sudden changes in environmental conditions (Cho et al. 2011; Poveda et al. 2012). Carbon fiber has good shock-absorbing performance, which allows it to achieve seismic repair and improve fastness in construction applications. Carbon fiber is anisotropic, with large design freedom, good deep processing performance, and strong adaptability to complex structures of equipment (Moskalyuk et al. 2015; Tane et al. 2019). Carbon fiber is a structural conductive material with inherent electrical and thermal conductivity. As a consequence of these characteristics, during the processing, there will be no excessive heat storage and overheating.

Currently, carbon fiber has formed an important new material system, and has been applied in many fields because of its excellent properties. In terms of overall properties, carbon fiber ranks first among the top five reinforcement materials (carbon fiber, boron fiber, silicon carbide fiber, alumina fiber, and kevlar fiber). It is usually used as a reinforcement material to prepare composite materials together with other materials for improving the properties of composite materials.

With the development of science and technology, the application field of carbon fiber composite materials is also expanding. At present, carbon fiber has become an indispensable new material in aerospace (Yang et al. 2014) and military industries (Yang et al. 2012). At the same time, it is being used for new applications in the civil industry field (Fitzer 1989), such as transportation, information, and communication, building materials, wind power generation, and so on. With the extensive application of carbon fiber, the social and economic benefits will be more significant.

\section{PREPARATION OF LIGNIN-BASED CARBON FIBER}

Research on the preparation of lignin-based carbon fibers was started in the last century. It was first prepared by Otani in Japan in 1965 (Otani 1968). He successfully prepared lignin-based carbon fibers by dry and wet spinning using lignin sulfonate in pulp. However, the mechanical properties were unsatisfactory. The United States and other western countries have made preliminary explorations and found that the internal molecules of lignin-based carbon fiber have no directionality, which is responsible for the performance of lignin-based fibers to be lower than that of pitch-based carbon fibers (Dave et al. 1993). Later, the lignin-based fibers were modified by a melt spinning 
technology, which provides a better method to prepare high-performance lignin-based carbon fibers (Kim et al. 2015).

The preparation of lignin-based carbon fibers mainly includes spinning, preoxidation, and carbonization. However, a key problem for the preparation is how to process lignin into fibers with a certain linear density and morphology. Furthermore, the mechanical properties of the fibers still needs to be maintained after stabilization and carbonization (Qin et al. 2013).

Currently, pretreatment steps, such as organic modification or blending with polymers, are being used to reduce the brittleness of lignin-based fibers and improve their spinnability. Then, the initial fibers are obtained via wet spinning, melt spinning, and electrospinning. Finally, the carbon fibers are prepared by post-treatment. The operation process is shown in Fig. 6.

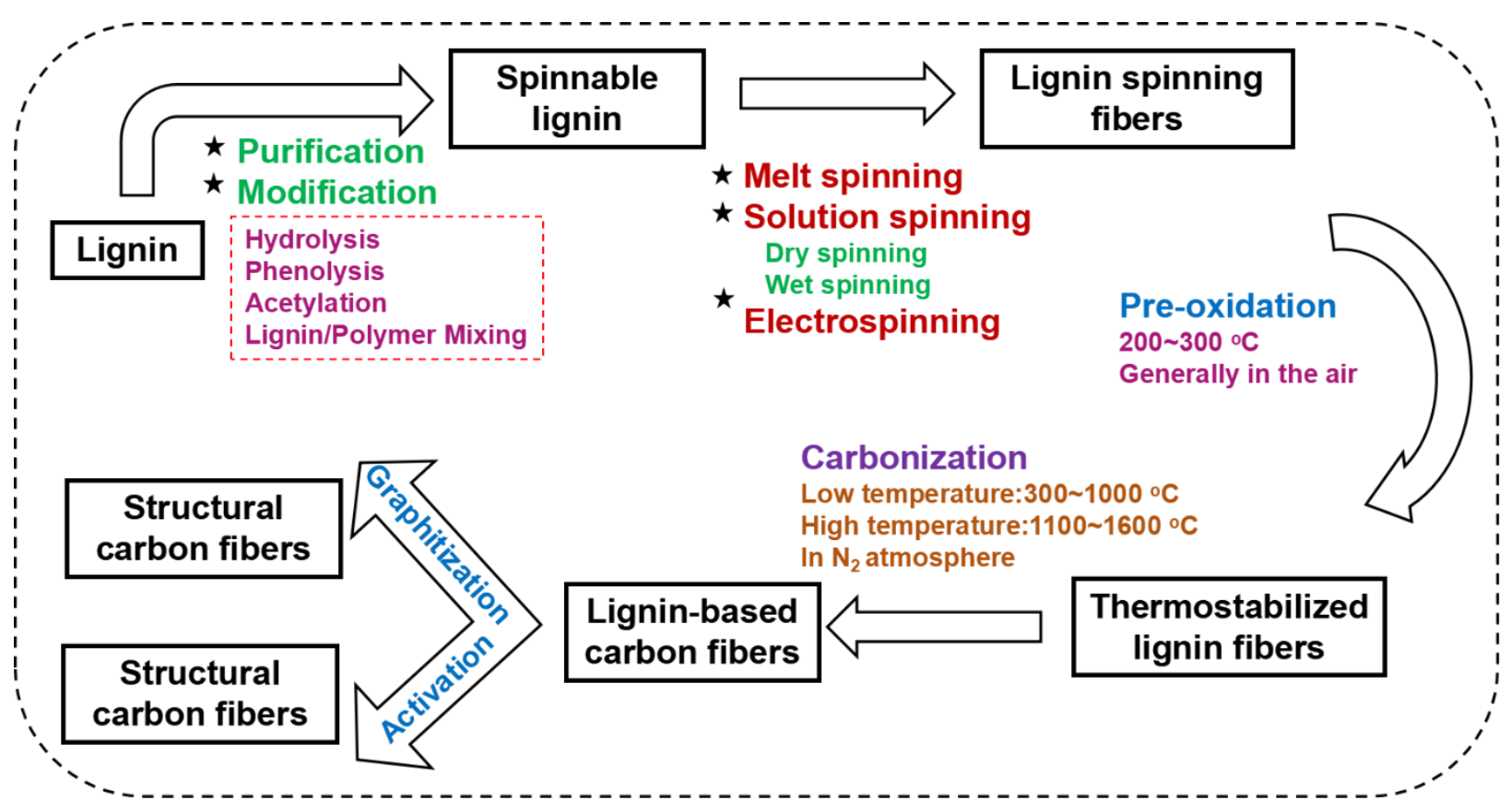

Fig. 6. The process of preparing carbon fiber from lignin

\section{Spinning}

Melt spinning

Melt spinning is the most common method of preparing lignin-based carbon fibers. It has the advantages of being a simple process with high material utilization and a small level of environmental pollution (Huang et al. 2019). Up to now, only organic lignin has been successfully melt-spun without being treated. However, the time required for stabilization is too long to be realistic (Kadla et al. 2002). Generally, hardwood lignin is more easily melt-spun than softwood lignin, while softwood lignin has a faster setting time than hardwood lignin due to the difference in chemical structures. Proper pretreatment, such as organic solvent liquefaction, blending with polymer, and chemical modification, all can contribute to improving the spinnability and efficiency.

For the first time, Kadla et al. (2002) used hardwood kraft lignin (HKL) without chemical modification to melt-spin at $200{ }^{\circ} \mathrm{C}$, and they then obtained carbon fiber with a tensile strength of $422 \pm 80 \mathrm{MPa}$ and a tensile modulus of $40 \pm 11 \mathrm{GPa}$ after simple heat treatment. 
Sudo and Shimizu (1992) used SEL to melt-spin at $50{ }^{\circ} \mathrm{C}$ after hydrocracking in vacuum. However, the viscosity was too low to form a filament after smelting. It was found that the melt spinning property was greatly improved after vacuum concentration at a temperature of 300 to $350{ }^{\circ} \mathrm{C}$. Then carbon fibers with a diameter of $7.6 \mu \mathrm{m}$ and a strength of $660 \mathrm{MPa}$ were obtained by pre-oxidation and carbonization. However, the yield of carbon fiber produced by this method was only $15.7 \%$ to $17.4 \%$. To further improve the yield of carbon fiber, Sudo et al. (1993) treated SEL with phenol to obtain lignin with good fluidity. The spinning fiber was prepared by melt spinning at $95{ }^{\circ} \mathrm{C}$. Compared to treatment with hydrocracking, the yield of carbon fiber treated with phenolic aldehyde was up to $43.7 \%$. Kadla and Kubo (2003) blended polyethylene oxide (PEO) with HKL for melt spinning, which not only improved the fiber forming performance, but also reduced the spinning temperature $\left(160\right.$ to $\left.232{ }^{\circ} \mathrm{C}\right)$. The final yield of carbon fiber was up to $45 \%$ when PEO content was $5 \%$. The content of hydroxyl groups in softwood kraft lignin (SKL) is more than that in HKL, which makes it easier to crosslink and lose melting property during heating. Therefore, SKL is more difficult to obtain spinning fiber under these conditions. Subsequently, Kubo and Kadla (2005) studied the compatibility between SKL and PEO, and the results showed that SKL and PEO have not only strong hydrogen bond interactions, but also relatively weak intermolecular interactions. Based on this theory, they blended PEO with SKL and prepared lignin-based fibers by melting spinning. However, the spinning temperature (220 to $240{ }^{\circ} \mathrm{C}$ ) was found to be higher than that of mixing PEO with HKL, and only when the proportion of PEO is higher than $37.5 \%$ can continuous spinning be realized. This further indicates that SKL melt spinning is more difficult than HKL.

Kubo et al. (1996) also studied the influence of pretreatment on the melt spinning process, including acetylation, saponification, and heat treatment. The results showed that lignin treated with acetylation had the highest spinnability. It was further investigated for the effects of molecular weight and soluble components on the melting properties of softwood lignin (Kubo et al. 1998). The results demonstrated that lignin could only be melted when the molecular weight was less than $3200 \mathrm{~g} \cdot \mathrm{mol}^{-1}$ or when the fusible component accounted for $58.2 \%$.

On the basis of this work, two directions to improve lignin melting properties were proposed by Kubo. One is to reduce the phenolic hydroxyl interaction in lignin molecules through acetylation, thus reducing the hydroxyl dehydration and cross-linking during heating. The other is to increase the proportion of molten lignin by molecular weight fractionation.

However, there are no suitable means to improve the lignin melting property for industrialization. At the same time, only general-grade lignin-based carbon fibers can be prepared by melt spinning, which is not suitable for preparing nano-scale materials and therefore their application scope is limited.

\section{Solution spinning}

Solution spinning is a method for preparing lignin-based carbon fibers with higher mechanical properties (Jin and Ogale 2018). It can be divided into wet spinning and dry spinning according to the curing mode. Wet spinning makes it easy to control the diameter of the fibers, and there is little residual solvent in the fibers. Dry spinning, however, is less often used due to the amount of voids and residual solvent in the fibers. Lignin-based carbon fiber with high tensile strength can be prepared by dry spinning. Zhang and Ogale (2014) obtained acetylated lignin, which can dissolve completely in 
acetone by modifying SKL with acetic anhydride. Then, carbon fibers with tensile strength of $1.04 \pm 0.10 \mathrm{GPa}$ were prepared by dry spinning, and this is the highest tensile strength of lignin-based carbon fibers reported up to now. However, the pre-oxidation process took a long time (at a heating rate of $0.01{ }^{\circ} \mathrm{C} / \mathrm{min}$ ), making it an unsuitable material for large-scale production.

Maradur et al. (2012) dissolved lignin and acrylonitrile oligomer in dimethyl sulfoxide (DMSO) and then obtained carbon fiber with good tensile properties through wet spinning and subsequent heat treatment. More importantly, the total yield of carbon fiber prepared by this method was up to $56 \%$, which provides a new idea for the preparation of low-cost lignin-based carbon fibers.

Lignin needs to be modified before solution spinning because of its poor solubility in organic solvents. Compared with melt spinning, solution spinning has a relatively high cost and a low efficiency in producing lignin-based carbon fibers. Therefore, there has been relatively little research on this aspect.

\section{Electrospinning}

Electrospinning is a special fiber manufacturing technology that has developed rapidly in recent years. When a polymer solution or melt is sprayed and spun in a strong electric field, the droplet at the tip of the needle changes from a sphere to a cone (known as a "Taylor cone") (Wang et al. 2016c), then extending from the tip of the cone to form filaments. In this way, polymer filaments with nanoscale diameters can be produced. The schematic diagrams of lignin electrospinning are shown as Fig. 7.

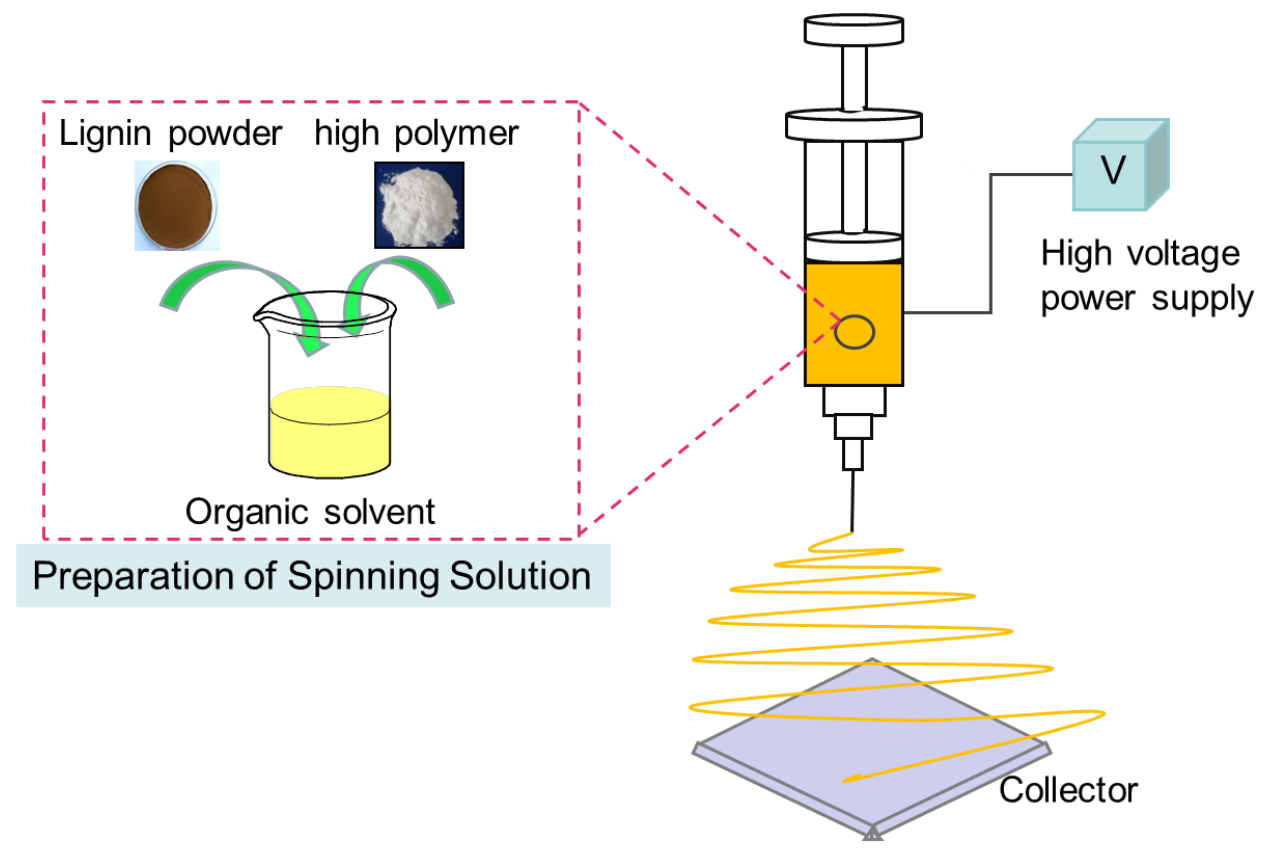

Fig. 7. Schematic diagrams of lignin electrospinning

Lignin is often mixed with polymer for electrostatic spinning, because of its poor conductivity and solubility (there are few solvents that can dissolve lignin). In addition, the pure lignin solution is difficult to form fiber during electrospinning, resulting in electrospray particles formed in this process. This has been demonstrated by relevant research. Dallmeyer et al. (2010) dissolved KL in N,N-dimethylformamide (DMF) 
solution. The spinning liquid could not obtain fibrous material under the action of a high voltage electric field. However, both SKL and HKL could obtain fibers with a smooth surface and micron diameter through electrospinning when PEO was added to the spinning solution. This indicated that the spinnability of lignin could be improved by blending polymer with lignin.

Feng and Aorigele (2009) produced uniform acetic acid lignin/polyvinylpyrrolidone (AAL/PVP) blend fibers by electrospinning. However, the solvent volatilizes too fast during spinning, which was not conducive to formation of fibers. Using trifluoroacetic acid as solvent, Svinterikos and Zuburtikudis (2016) prepared a kraft lignin/polyethylene terephthalate (KL/PET) blended carbon fiber mat by electrospinning, which had a nanometer diameter and a carbon content of $94.3 \%$.

The advantage of electrospinning is that carbon fiber can be prepared at the nanoscale level, which is impossible for melt spinning and solution spinning methods. Therefore, electrospinning is often used to produce products with specific performance requirements. At the same time, the method also has shortcomings such as low fiber yield, poor orientation, and low strength (Teo et al. 2011; Lu et al. 2014). Currently, the preparation of carbon nanofibers based on lignin by electrospinning is mainly in the experimental stage, and it still needs to overcome a difficult problem to realize industrial production.

\section{Pre-oxidation}

Pre-oxidation is a subsequent step after obtaining the spinning fiber. Pre-oxidation is one of the most time-consuming and important intermediate processes in carbon fiber production (Dave et al. 1993; Newcomb 2016), which not only controls the quality of carbon fiber, but also determines the yield of carbon fiber. The purpose of pre-oxidation is to improve the mechanical properties of the fiber by converting the macromolecular chain of the polymer into a stable structure, so that pre-oxidized fiber will not melt or burn in the subsequent high-temperature carbonization stage and the obtained ligninbased carbon fiber will maintain the fiber morphology as well as thermodynamic stable state (Gupta and Harrison 1997). Lignin spinning fibers are susceptible to bonding and crosslinking at high temperature if carbonized directly. Therefore, it is necessary to carry out pre-oxidation treatment before carbonization (Niu et al. 2011; Newcomb 2016).

Pre-oxidation is usually carried out in an oxygen atmosphere at temperatures in the range of 200 to $300{ }^{\circ} \mathrm{C}$. The selection of heating rate directly affects the mechanical properties of carbon fiber (Ji et al. 2007; Zhang et al. 2018). Incorrect process conditions may lead to insufficient or excessive pre-oxidation, further resulting in structural defects of fibers and low mechanical properties (Liu et al. 2018b). Therefore, the optimum preoxidation time must be optimized according to the experiment.

The chemical and structural changes caused by heat treatment in the pre-oxidation process are complex. Up to this point, it has not been fully recognized and understood for the following reasons. The first reason is that spinning fiber is composed of two or more monomers. The type and content of the monomers affect thermal stability of the spinning fiber. The second reason is the diversity of physical aggregation structure caused by the processing of spinning fiber, such as diameter, crystal morphology, and orientation. The third reason is that the diffusion and reaction of oxygen are not homogeneous in the process of thermal stabilization.

The pre-oxidation step is where the orientation loss usually occurs. Higher molecular orientation could improve the mechanical properties of the fiber. A critical 
process parameter for carbon fiber is tension during oxidative-stabilization. Researchers at Clemson University reported studies (Zhang and Ogale 2014) that maintain molecular orientation by applying tension during preoxidation . Using a commercial SKL as raw material, they acetylated the raw fiber to obtain different degrees of substitution. Then the thermal stabilization was carried out under applied tension. The results showed that the fibers had obvious molecular orientation under applied tension. The diameter of the fiber became thinner and the tensile strength increased. During pre-oxidation and carbonation, the tensile strength of fibers treated without tension was only half that of fibers treated with tension. The research group also investigated the effects of the addition of photoinitiators and further UV exposure on the properties of the synthesized PAN and preoxidized fibers (Mrales and Ogale 2013). 1wt \% of photogenic agent (4,4'bis(dilamino)benzophenone) was added to the PAN and 5 minutes of UV irradiation was applied. The results showed that the traditional stabilization time of thermal oxidation can be significantly reduced. This indicates that these two treatments have potential in preparing more molecular-oriented precursors and may shorten the time of thermal oxidation in carbon fiber processing.

\section{Carbonization}

The carbonization is an important step in the transformation of the structure and properties of carbon fiber. The purpose is to make the material undergo crosslinking, cracking, condensation, and other chemical reactions by heating under inert gas protection, resulting in the formation of a disordered layer of graphite structure. Finally, carbon fiber with disordered graphite structure is obtained (Wang et al. 2016b).

The whole process of carbonization is divided into two stages: low temperature carbonization at 300 to $1000{ }^{\circ} \mathrm{C}$ and high temperature carbonization at 1100 to $1600{ }^{\circ} \mathrm{C}$. However, the signature carbonization temperature is $700{ }^{\circ} \mathrm{C}(\mathrm{Hu}$ et al. 2017; Salim et al. 2018), which is also the boundary temperature between low-temperature and hightemperature carbonization.

Research on the influence of carbonization conditions on the structure and properties of carbon fiber showed that the relative importance of different carbonization conditions was as follows: heating rate > carbonization final temperature > holding time (Ma and Zhao 2011). Within a certain range, the lower the heating rate, the higher the carbonization temperature, and the longer the holding time, the greater the tensile strength and modulus of the obtained carbon fiber (Baker et al. 2012). When carbonization temperature exceeds a certain value, the tensile strength of carbon fiber will decrease. The reasons are as follows: On the one hand, with the gradual increase of carbonization temperature, non-carbon heteroatoms (mainly $\mathrm{N}$ ) become further exited, which enriches elemental carbon and finally forms disordered layer graphite structure. During this process, the tensile strength of carbon fiber increases gradually. When the bulk density of disordered graphite structure is balanced with the preferred orientation of fiber, the tensile strength reaches its maximum value. On the other hand, when the carbonization temperature reaches the optimal temperature, a large amount of $\mathrm{N}$ element comes out in the form of $\mathrm{N}_{2}$, which increases the fiber pores and defects and further leads to the decline of tensile strength.

Table 4 summarizes the preparation of lignin-based carbon fibers by different methods. 
Table 4. Summary of Preparation of Lignin-based Carbon Fiber

\begin{tabular}{|c|c|c|c|c|c|}
\hline \multirow{10}{*}{ 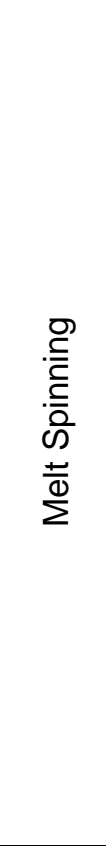 } & \multicolumn{2}{|c|}{$\begin{array}{c}\text { Lignin } \\
\text { Treatment }\end{array}$} & Spinning System & $\begin{array}{l}\text { Preoxidation/ } \\
\text { Carbonization }\end{array}$ & Result \\
\hline & \multicolumn{2}{|r|}{ No } & HKL & $\begin{array}{c}250^{\circ} \mathrm{C}(12 \text { to } \\
\left.180^{\circ} \mathrm{C} / \mathrm{h}\right) \\
1000^{\circ} \mathrm{C}\left(180^{\circ} \mathrm{C} / \mathrm{h}\right)\end{array}$ & $\begin{array}{l}\text { Carbon fibers with } \\
\text { tensile strength ( } 422 \\
\text { MPa), modulus ( } 40 \\
\text { GPa) }\end{array}$ \\
\hline & \multicolumn{2}{|c|}{ Acetylation } & OL & - & Improved spinnability \\
\hline & \multicolumn{2}{|c|}{ Hydrocracking } & SEL & $\begin{array}{l}210^{\circ} \mathrm{C}\left(1-2^{\circ} \mathrm{C} / \mathrm{min}\right) \\
1000^{\circ} \mathrm{C}\left(5^{\circ} \mathrm{C} / \mathrm{min}\right)\end{array}$ & Low yield \\
\hline & \multicolumn{2}{|c|}{ Phenolics } & SEL & $\begin{array}{c}210^{\circ} \mathrm{C}\left(1 \text { to } 2^{\circ} \mathrm{C}\right. \\
/ / \min ) \\
1000^{\circ} \mathrm{C}\left(5^{\circ} \mathrm{C} / \mathrm{min}\right)\end{array}$ & $\begin{array}{l}\text { Yield } 43.7 \% \text {, tensile } \\
\text { strength } 400 \mathrm{MPa}\end{array}$ \\
\hline & \multirow{5}{*}{\multicolumn{2}{|c|}{$\begin{array}{l}\text { Mixing with } \\
\text { polymers }\end{array}$}} & HKL/ PEO & $210^{\circ} \mathrm{C}$ & Yield up to $45 \%$ \\
\hline & & & $\mathrm{HKL} / \mathrm{PP}$ & $\begin{array}{c}250^{\circ} \mathrm{C}\left(18^{\circ} \mathrm{C} / \mathrm{h}\right) \\
1000^{\circ} \mathrm{C}\left(180^{\circ} \mathrm{C} / \mathrm{h}\right)\end{array}$ & Carbon fiber with void \\
\hline & & & KL/PVA & $\begin{array}{l}220^{\circ} \mathrm{C}\left(0.5^{\circ} \mathrm{C} / \mathrm{min}\right) \\
1200^{\circ} \mathrm{C}\left(5^{\circ} \mathrm{C} / \mathrm{min}\right)\end{array}$ & $\begin{array}{l}\text { Microporous carbon } \\
\text { fiber }\end{array}$ \\
\hline & & & HKL/PET & $\begin{array}{c}250^{\circ} \mathrm{C}\left(12-180^{\circ} \mathrm{C} / \mathrm{h}\right) \\
1000^{\circ} \mathrm{C}\left(180^{\circ} \mathrm{C} / \mathrm{h}\right)\end{array}$ & Fiber obtained \\
\hline & & & SKL/PLA & $\begin{array}{c}280^{\circ} \mathrm{C}\left(0.25^{\circ} \mathrm{C} / \mathrm{min}\right) \\
1000^{\circ} \mathrm{C}\left(3^{\circ} \mathrm{C} / \mathrm{min}\right)\end{array}$ & $\begin{array}{l}\text { High tensile modulus } \\
\text { and low tensile strength }\end{array}$ \\
\hline \multirow{2}{*}{ 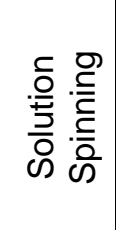 } & ลิ & Acetylation & SKL & $\begin{array}{l}220^{\circ} \mathrm{C}\left(0.2^{\circ} \mathrm{C} / \mathrm{min}\right) \\
1000^{\circ} \mathrm{C}\left(4.5^{\circ} \mathrm{C} / \mathrm{min}\right)\end{array}$ & $\begin{array}{c}\text { Sawtooth fibers, highest } \\
\text { tensile strength (1.04 } \\
\text { GPa) }\end{array}$ \\
\hline & $\stackrel{ \pm}{3}$ & & L/PAN & $\begin{array}{l}280^{\circ} \mathrm{C}\left(1^{\circ} \mathrm{C} / \mathrm{min}\right) \\
800^{\circ} \mathrm{C}\left(5^{\circ} \mathrm{C} / \mathrm{min}\right)\end{array}$ & Yield up to $56 \%$ \\
\hline \multirow{4}{*}{ 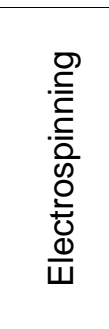 } & \multirow{4}{*}{\multicolumn{2}{|c|}{$\begin{array}{l}\text { Blending with } \\
\text { polymer }\end{array}$}} & L/PAN & $\begin{array}{l}250^{\circ} \mathrm{C}\left(20^{\circ} \mathrm{C} / \mathrm{h}\right) \\
1000^{\circ} \mathrm{C}\left(10^{\circ} \mathrm{C} / \mathrm{h}\right)\end{array}$ & Nanofibers obtained \\
\hline & & & $\begin{array}{l}\text { SKL (or } \\
\text { HKL)/PEO }\end{array}$ & $\begin{array}{c}250^{\circ} \mathrm{C}\left(5^{\circ} \mathrm{C} / \mathrm{min}\right) \\
1000^{\circ} \mathrm{C}\left(10^{\circ} \mathrm{C} / \mathrm{min}\right)\end{array}$ & Micron fibers obtained \\
\hline & & & AAL/PVP & $\begin{array}{l}250^{\circ} \mathrm{C}\left(0.5^{\circ} \mathrm{C} / \mathrm{min}\right) \\
700^{\circ} \mathrm{C}\left(100^{\circ} \mathrm{C} / \mathrm{h}\right)\end{array}$ & $\begin{array}{l}\text { Solvent evaporates } \\
\text { quickly, poor fibrillation }\end{array}$ \\
\hline & & & KL/PET & $\begin{array}{l}260^{\circ} \mathrm{C}\left(120^{\circ} \mathrm{C} / \mathrm{h}\right) \\
1000^{\circ} \mathrm{C}\left(180^{\circ} \mathrm{C} / \mathrm{h}\right)\end{array}$ & Nanofibers obtained \\
\hline \multicolumn{6}{|c|}{$\begin{array}{l}\text { ^ L: Lignin; PAN: Polyacrylonitrile; HKL: Hardwood kraft lignin; OL: Organosolv lignin; SEL: Steam } \\
\text { explosion lignin; PEO: Polyethylene oxide; PP: Polypropylene; PVA: Polyvinyl alcohol; PET: } \\
\text { Polyethylene terephthalate; SKL: Softwood kraft lignin; PLA: Polylactic acid; AAL: Acetic acid } \\
\text { lignin; PVP: Polyvinylpyrrolidone; KL: Kraft lignin }\end{array}$} \\
\hline
\end{tabular}




\section{CURRENT PROBLEMS IN PREPARATION OF CARBON FIBERS FROM LIGNIN}

The tensile strength of lignin-based carbon fibers is usually between 350 and 550 MPa (Mainka et al. 2015). Micro-nanometer lignin-based carbon fibers can be prepared by electrostatic spinning (Carrott and Carrott 2007), and the smaller the diameter, the greater the mechanical strength. Currently, the mechanical strength of lignin-based carbon fibers is still low due to the material impurities and low molecular weight of lignin, which limits the application of lignin-based carbon fibers.

Among many types of industrial lignin, sulfate lignin has the most single structures and high purity, so it is often used to prepare carbon fiber. There are also reports from research institutions and schools on the preparation of lignin-based carbon fibers from alkali lignin. During pulping and papermaking, the lignin sulfonate substructure is seriously damaged. At the same time, many inorganic salt impurities with complex components remain, which are difficult to remove. Based on this, lignin sulfonate is not suitable for the preparation of lignin-based carbon fibers. Steam blast lignin and organic solvent lignin experience less structural damage and fewer impurities in the process of separation and extraction. However, the requirements of extraction conditions are strict and the cost is high, which makes large-scale production difficult.

\section{TECHNICAL EVALUATION}

The lack of a clear molecular orientation of lignin is the main reason why the mechanical properties of lignin-based carbon fibers are lower than those of PAN-based carbon fibers. This deficiency in strength limits the application of lignin-based carbon fibers.

Unfortunately, the paper and pulp industries tend to maximize the extraction of raw lignin without considering the structural protection of lignin macromolecules. The purity and separation methods of lignin determine the quality of recovered lignin to a large extent. These are the factors to be considered in the preparation of carbon fiber from lignin. In addition to the correct heating rate, each material may have an optimum temperature during the heating.

Lignin is a natural, partially oxidized substance that requires strict control of the spinning process. Additionally, the integrity of lignin fibers depends on the crosslinking capability of the fibers during the thermal stabilization of pre-oxidation. Lignin should have a narrow molecular weight distribution (with little difference between glass transition temperature $\left(T_{\mathrm{g}}\right)$ and softening temperature $\left.\left(T_{\mathrm{s}}\right)\right)$ to ensure that the molecular weight of lignin increases evenly during thermal stabilization of oxidation. Further, a more uniform carbon fiber structure is provided in the process of the carbonization process.

The $T_{\mathrm{g}}$ of lignin is influenced by the ratios of phenyl propane units $(\mathrm{S}, \mathrm{G}$, and $\mathrm{H}$ ) and molecular weight, of which the influence of the former is more important. Molecular weight measurement is difficult because different lignin may have different properties, such as chemical composition, chemical structure, degree of branching, and relative solubility, etc. Based on this, it can be concluded that the $T_{\mathrm{g}}$ of lignin containing more $\mathrm{S}$ (hardwood) is lower than that of lignin containing more G (softwood), and then lower than that of lignin containing more $\mathrm{G}$ and $\mathrm{H}$ (grass). 
Research on the pre-oxidation and carbonization optimization of lignin is helpful to improve the strength of lignin-based carbon fibers. It should be noted that in addition to the correct heating rate, each material may have an optimum temperature during the heating process. Currently, the process parameters of lignin filament in the pre-oxidation and carbonization stages refer to those of the preparation process of PAN-based carbon fibers, while the thermochemical mechanism involved in the transformation is completely different.

Moreover, lignin has ultraviolet absorption characteristics. The ultraviolet-visible (UV-vis) test of the lignin fiber film obtained from electrospinning shows that the electrospun lignin fiber film absorbs ultraviolet light. This demonstrates the potential of lignin electrospinning films in ultraviolet applications. Based on this, electrospun lignin fiber film can be directly used in the field of ultraviolet absorption without carbonization.

In addition, taking advantage of the existing characteristics of electrospun fiber in the form of film, carbon fiber is also used as a new power source in the field of supercapacitors, which has the advantage of high weight ratio capacitance. Without the addition of conductive material and binder, it can be used directly as electrode material in the form of film. A novel electrode synthesis method was proposed in Oak Ridge Laboratory (Tenhaeff et al. 2014). Lignin-based carbon fiber felt was used as electrode material by scalable melt processing technology. The resulting independent electrode is comparable to commercial carbon-based anodes in material and processing costs. The results showed that carbonized felt can realize reversible cycling in conventional aprotic organic electrolyte, and its coulomb effect exceeds $99.9 \%$. This dual function eliminates the need for large metal current collectors and polymer adhesives in traditional electrode designs. Not only the production process is simple, but it also avoids the problem of rising resistance caused by the use of binder, which shows the application prospect of lignin-based carbon fiber. This is not only conducive to the comprehensive utilization of lignin resources, but also conducive to the development of clean energy.

\section{CONCLUSIONS}

1. It is feasible to convert lignin, with abundant reserves and high carbon content, into low-cost carbon fiber. Thus, lignin has great potential and development prospects in the preparation of low-cost carbon fiber.

2. With the continuous progress of science and technology, lignin-based carbon fibers have become a material with good economic attractiveness and environmental sustainability. The research of lignin-based carbon fiber not only broadens the utilization direction of lignin, but it also alleviates the shortage of carbon fiber in the current market, which shows good social and economic benefits.

\section{ACKNOWLEDGMENTS}

The authors would like to acknowledge the National Natural Science Foundation of China (21978161), the High-level Foreign Experts Project (GDT20186100425), and the Academic Leaders Program of Shaanxi University of Science \& Technology (2013XSD25). 


\section{REFERENCES CITED}

Alway-Cooper, R. M., Anderson, D. P., and Ogale, A. A. (2013). "Carbon black modification of mesophase pitch-based carbon fibers," Carbon 59, 40-48. DOI: 10.1016/j.carbon.2013.02.048

Asano, K. (2017). "Thermal expansion behaviour of squeeze-cast aluminium matrix composites reinforced with PAN- and pitch-based carbon fibres," International Journal of Cast Metals Research 30(6), 365-373. DOI:

10.1080/13640461.2017.1323606

Baker, D. A., Gallego, N. C., and Baker, F. S. (2012). "On the characterization and spinning of an organic-purified lignin toward the manufacture of low-cost carbon fiber," Journal of Applied Polymer Science 124(1), 227-234. DOI: 10.1002/app.33596

Baker, D. A., and Rials, T. G. (2013). "Recent advances in low-cost carbon fiber manufacture from lignin," Journal of Applied Polymer Science 130(2), 713-728. DOI: 10.1002/app.39273

Beste, A., and Buchanan, A. C. I. (2012). "Role of carbon-carbon phenyl migration in the pyrolysis mechanism of beta-O-4 lignin model compounds: Phenethyl phenyl ether and alpha-hydroxy phenethyl phenyl ether," Journal of Physical Chemistry A 116(50), 12242-12248. DOI: 10.1021/jp3104694

Bolker, H. I., and Brenner, H. S. (1970). "Polymeric structure of spruce lignin," Science 170(3954), 173-176. DOI: 10.1126/science.170.3954.173

Carrott, P., and Carrott, M. R. (2007). "Lignin-from natural adsorbent to activated carbon: A review," Bioresource Technology 98(12), 2301-2312. DOI:

10.1016/j.biortech.2006.08.008

Cho, M., Jang, J., and Suhr, J. (2011). "Effect of filler geometry on coefficient of thermal expansion in carbon nanofiber reinforced epoxy composites," Journal of Nanoscience and Nanotechnology 11(2), 1098-1102. DOI: 10.1166/jnn.2011.3111

Culica, M. E., Biliuta, G., Rotaru, R., Lisa, G., Baron, R. I., and Coseri, S. (2019). "New electromagnetic shielding materials based on viscose-carbon nanotubes composites," Polymer Engineering and Science 59(7), 1499-1506. DOI: 10.1002/pen.25149

Dallmeyer, I., Ko, F., and Kadla, J. F. (2010). "Electrospinning of technical lignins for the production of fibrous networks," Journal of Wood Chemistry and Technology 30(4), 315-329. DOI: 10.1080/02773813.2010.527782

Dave, V., Prasad, A., Marand, H., and Glasser, W. G. (1993). "Molecular organization of lignin during carbonization," Polymer 34(15), 3144-3154. DOI: 10.1016/00323861(93)90382-K

Duval, A., Molina-Boisseau, S., and Chirat, C. (2013). "Comparison of kraft lignin and lignosulfonates addition to wheat gluten-based materials: Mechanical and thermal properties," Industrial Crops and Products 49, 66-74. DOI: 10.1016/j.indcrop.2013.04.027

Fechter, C., and Heinze, T. (2019). "Influence of wood pulp quality on the structure of carboxymethyl cellulose," Journal of Applied Polymer Science 136(34), 4786247866. DOI: 10.1002/app.47862

Feng, Y., and Aorigele (2009). "Preparation of lignin-based nanofibers by electrospinning," Paper Science \& Technology 28(5), 29-32. (In Chinese) DOI: 10.3969/j.issn.1671-4571.2009.05.008 
Fitzer, E. (1989). "Pan-based carbon fibers - present state and trend of the technology from the viewpoint of possibilities and limits to influence and to control the fiber properties by the process parameters," Carbon 27(5), 621-645. DOI: 10.1016/00086223(89)90197-8

Frank, E., Hermanutz, F., and Buchmeiser, M. R. (2012). "Carbon fibers: Precursors, manufacturing, and properties," Macromolecular Materials and Engineering 297(6), 493-501. DOI: $10.1002 /$ mame.201100406

Gao, T., Zhao, Y., Zhou, G., Han, Y., Zheng, Y., Shan, Z., Hui, D., Xu, F., and Qiu, Y. (2015). "Fabrication and characterization of three dimensional woven carbon fiber/silica ceramic matrix composites," Composites Part B: Engineering 77, 122128. DOI: 10.1016/j.compositesb.2015.02.024

Gorina, V. A., and Cheblakova, E. G. (2016). "Influence of activation modes on the specific surface and development of a microporous structure of viscose-based carbon fibers," Russian Journal of Non-Ferrous Metals 57(7), 734-738. DOI: $10.3103 / \mathrm{S} 1067821216070087$

Gupta, A., and Harrison, I. R. (1997). "New aspects in the oxidative stabilization of PANbased carbon fibers," Carbon 34(11), 1427-1445. DOI: 10.1016/s00086223(97)00025-0

Harfouche, A., Grant, K., Selig, M., Tsai, D., and Meilan, R. (2010). "Protecting innovation: Genomics-based intellectual property for the development of feedstock for second-generation biofuels," Recent Patents on DNA \& Gene Sequences 4(2), 94105. DOI: $10.2174 / 187221510793205737$

Hirayama, H., Akiyama, T., Kimura, S., Nawawi, D. S., Syafii, W., Yokoyama, T., and Matsumoto, Y. (2019). "Influence of the p-hydroxyphenyl/guaiacyl ratio on the biphenyl and beta-5 contents in compression wood lignins," Holzforschung 73(10), 923-935. DOI: 10.1515/hf-2019-0012

Horhammer, H., Walton, S., and Van Heiningen, A. (2011). "A larch based biorefinery: Pre-extraction and extract fermentation to lactic acid," Holzforschung 65(4), 491-496. DOI: 10.1515/HF.2011.085

Hu, Z., Jin, S., Lu, W., Tang, S., Guo, C., Lu, Y., Zhang, R., Liu, Y., and Jin, M. (2017). "Effect of carbonization temperature on microwave absorbing properties of polyacrylonitrile-based carbon fibers," Fullerenes Nanotubes and Carbon Nanostructures 25(11), 637-641. DOI: 10.1080/1536383X.2017.1372751

Huang, Y., Liu, H., Xiao, C., Wang, C., Chen, D., and Sun, K. (2019). "Robust preparation and multiple pore structure design of poly (tetrafluoroethylene-cohexafluoropropylene) hollow fiber membrane by melt spinning and post-treatment," Journal of the Taiwan Institute of Chemical Engineers 97, 441-449. DOI: 10.1016/j.jtice.2019.02.010

Jafarpour, G., Roig , F., Dantras, E., Boudet, A., and Lacabanne, C. (2009). "Influence of water on localized and delocalized molecular mobility of cellulose," Journal of Non Crystalline Solids 355(34-36), 1669-1672. DOI: 10.1016/j.jnoncrysol.2009.06.026

Jenkins, D. H. R., Forster, I. W., McKibbin, B., and Rlis, Z. A. (1997). "Induction of tendon and ligament formation by carbon implants," Journal of Bone \& Joint Surgery British Volume 59(1), 53-7. DOI: 10.1007/BF00266342 
Jenkins, D. H. R., and McKibbin, B. (1980). "The role of flexible carbon-fibre implants as tendon and ligament substitutes in clinical practice," The Bone \& Joint Journal 62B(4), 497-499. DOI: 10.1302/0301-620X.62B4.7430232

Ji, M., Wang, C., Bai, Y., Yu, M., and Wang, Y. (2007). "Structural evolution of polyacrylonitrile precursor fibers during preoxidation and carbonization," Polymer Bulletin 59(4), 527-536. DOI: 10.1007/s00289-007-0796-3

Jiang, G., Pickering, S. J., Lester, E. H., Turner, T. A., Wong, K. H., and Warrior, N. A. (2009). "Characterisation of carbon fibres recycled from carbon fibre/epoxy resin composites using supercritical n-propanol," Composites Science and Technology 69(2), 192-198. DOI: 10.1016/j.compscitech.2008.10.007

Jin, J., and Ogale, A. A. (2018). "Carbon fibers derived from wet-spinning of equicomponent lignin/polyacrylonitrile blends," Journal of Applied Polymer Science 135(8), Article number 45903. DOI: 10.1002/app.45903

Kadla, J. F., and Kubo, S. (2003). "Miscibility and hydrogen bonding in blends of poly(ethylene oxide) and kraft lignin," Macromolecules 36(20), 7803-7811. DOI: $10.1021 / \mathrm{ma0348371}$

Kadla, J. F., Kubo, S., Venditti, R. A., Gilbert, R. D., Compere, A. L., and Griffith, W. (2002). "Lignin-based carbon fibers for composite fiber applications," Carbon 40(15), 2913-2920. DOI: 10.1016/s0008-6223(02)00248-8

Kim, M. S., Lee, D. H., Kim, C. H., Lee, Y. J., Hwang, J. Y., Yang, C. M., Kim, Y. A., and Yang, K. S. (2015). "Shell-core structured carbon fibers via melt spinning of petroleum- and wood-processing waste blends," Carbon 85, 194-200. DOI: 10.1016/j.carbon.2014.12.100

Kim, S., Kuk, Y. S., Chung, Y. S., Yong, S., Jin, F. L., and Park, S. J. (2014). "Preparation and characterization of polyacrylonitrile-based carbon fiber papers," Journal of Industrial \& Engineering Chemistry 20(5), 3440-3445. DOI: 10.1016/j.jiec.2013.12.032

Kubo, S., and Kadla, J. F. (2005). "Kraft lignin/poly(ethylene oxide) blends: Effect of lignin structure on miscibility and hydrogen bonding," Journal of Applied Polymer Science 98(3), 1437-1444. DOI: 10.1002/app.22245

Kubo, S., Uraki, Y., and Sano, Y. (1996). "Thermomechanical analysis of isolated lignins," Holzforschung 50(2), 144-150. DOI: 10.1515/hfsg.1996.50.2.144

Kubo, S., Uraki, Y., and Sano, Y. (1998). "Preparation of carbon fibers from softwood lignin by atmospheric acetic acid pulping," Materials Science 36(7-8), 1119-1124. DOI: 10.1016/S0008-6223(98)00086-4

Laurichesse, S., and Averous, L. (2014). "Chemical modification of lignins: Towards biobased polymers," Progress in Polymer Science 39(7), 1266-1290. DOI:

10.1016/j.progpolymsci.2013.11.004

Lauwaert, J., Stals, I., Lancefield, C. S., Deschaumes, W., Depuydt, D., Vanlerberghe, B., Devlamynck, T., Bruijnincx, P. C. A., and Verberckmoes, A. (2019). "Pilot scale recovery of lignin from black liquor and advanced characterization of the final product," Separation and Purification Technology 221, 226-235. DOI: 10.1016/j.seppur.2019.03.081

Lebo, Jr., S. E., Gargulak, J. D., and McNally, T. J. (2000). "Lignin," in: Kirk-Othmer Encyclopedia of Chemical Technology, John Wiley \& Sons, Inc., Hoboken, NJ, USA. 
Lee, E. S., Kim, J. S., Kim, K. Y., Lim, D. Y., and Kim, D. H. (2014). "Preparation of polypropylene composites reinforced with long carbon fibers and their properties," Fibers and Polymers 15(12), 2613-2617. DOI: 10.1007/s12221-014-2613-6

Lee, J. S., and Rhee, I. (2019). "Functional properties of a pitch-based carbon fibermortar composite as a thin overlay for concrete pavement," Materials 12(17), Article number 2753. DOI: 10.3390/ma12172753

Li, N., Wu, S. P., and Liu, C. H. (2008). "Investigation of static and dynamic response of graphite and carbon fiber modified conductive asphalt-based composite," Key

Engineering Materials 385-387, 469-472. DOI:

10.4028/www.scientific.net/KEM.385-387.469

Li, Q., Serem, W. K., Dai, W., Yue, Y., Naik, M. T., Xie, S., Karki, P., Liu, L., Sue, H. J., and Liang, H. et al. (2017). "Molecular weight and uniformity define the mechanical performance of lignin-based carbon fiber," Journal of Materials Chemistry A 5(25), 12740-12746. DOI: 10.1039/C7TA01187C

Li, Z., Cai, Z., Zeng, Q., Zhang, T., France, L. J., Song, C., Zhang, Y., He, H., Jiang, L., and Long, J., et al. (2018). "Selective catalytic tailoring of the $\mathrm{H}$ unit in herbaceous lignin for methyl p-hydroxycinnamate production over metal-based ionic liquids," Green Chemistry 20(16), 3743-3752. DOI: 10.1039/C8GC01252K

Liitia, T. M., Maunu, S. L., Hortling, B., Toikka, M., and Kilpelainen, I. (2003). "Analysis of technical lignins by two- and three-dimensional NMR spectroscopy," Journal of Agricultural and Food Chemistry 51(8), 2136-2143. DOI: 10.1021/jf0204349

Lim, T. H., Kim, M. S., Yeo, S. Y., and Jeong, E. (2019). "Preparation and evaluation of isotropic and mesophase pitch-based carbon fibers using the pelletizing and continuous spinning process," Journal of Industrial Textiles 48(7), 1242-1253. DOI: $10.1177 / 1528083718763774$

Lindgren, B. O., Nilsson, T., Liljefors, T., and Sandström, J. (1974). "Oxidation of lignin model compounds with chlorine dioxide and chlorite. Reactions with stilbenes," Acta Chemica Scandinavica B 28(9), 847-852. DOI: 10.3891/acta.chem.scand.28b-0847

Liu, B., Qian, S., Dai, H., and Ren, H. (2017). "Separation of cell wall components by kraft pulping and their utilization for oil absorption," BioResources 12(2), 3043-3056. DOI: 10.15376/biores. 12.2.3043-3056

Liu, H. C., Chien, A. T., Newcomb, B. A., Liu, Y., and Kumar, S. (2015). "Processing, structure, and properties of lignin-and CNT-incorporated polyacrylonitrile-based carbon fibers," ACS Sustainable Chemistry \& Engineering 3(9), 1943-1954. DOI: 10.1021/acssuschemeng.5b00562

Liu, J., Shimanoe, H., Nakabayashi, K., Miyawaki, J., Ko, S., Jeon, Y. P., and Yoon, S. H. (2018a). "Preparation of isotropic pitch precursor for pitch-based carbon fiber through the co-carbonization of ethylene bottom oil and polyvinyl chloride," Journal of Industrial and Engineering Chemistry 67, 276-283. DOI: 10.1016/j.jiec.2018.06.039

Liu, J., Xiao, S., Shen, Z., Xu, L., Zhang, L., and Peng, J. (2018b). "Study on the oxidative stabilization of polyacrylonitrile fibers by microwave heating," Polymer Degradation and Stability 150, 86-91. DOI: 10.1016/j.polymdegradstab.2018.02.017

Liu, Y., and Kumar, S. (2012). "Recent progress in fabrication, structure, and properties of carbon fibers," Polymer Reviews 52(3-4), 234-258. DOI: 10.1080/15583724.2012.705410 
Lu, W., Sun, J., and Jiang, X. (2014). "Recent advances in electrospinning technology and biomedical applications of electrospun fibers," Journal of Materials Chemistry B 2(17), 2369-2380. DOI: 10.1039/C3TB21478H

Ma, X., and Zhao, G. (2011). "Variations in the microstructure of carbon fibers prepared from liquefied wood during carbonization," Journal of Applied Polymer Science 121(6), 3525-3530. DOI: 10.1002/app.34142

Macia-Agullo, J. A., Moore, B. C., Cazorla-Amoros, D., and Linares-Solano, A. (2007). "Influence of carbon fibres crystallinities on their chemical activation by $\mathrm{KOH}$ and $\mathrm{NaOH}, "$ Microporous and Mesoporous Materials 101(3), 397-405. DOI: 10.1016/j.micromeso.2006.12.002

Mainka, H., Hilfert, L., Busse, S., Edelmann, F., Haak, E., and Herrmann, A. S. (2015). "Characterization of the major reactions during conversion of lignin to carbon fiber," Journal of Materials Research and Technology 4(4), 377-391. DOI: 10.1016/j.jmrt.2015.04.005

Maradur, S. P., Chang, H. K., Kim, S. Y., Kim, B. H., Kim, W. C., and Yang, K. S. (2012). "Preparation of carbon fibers from a lignin copolymer with polyacrylonitrile," Synthetic Metals 162(5-6), 453-459. DOI: 10.1016/j.synthmet.2012.01.017

Matsumoto, M., Iwashita, T., Arai, Y., and Tomioka, T. (1993). "Effect of spinning conditions on structures of pitch-based carbon fiber," Carbon 31(5), 715-720. DOI: 10.1016/0008-6223(93)90008-X

Matsushita, Y., Sano, H., Imai, M., Imai, T., and Fukushima, K. (2007). "Phenolization of hardwood sulfuric acid lignin and comparison of the behavior of the syringyl and guaiacyl units in lignin," Journal of Wood Science 53(1), 67-70. DOI: 10.1007/s10086-006-0814-3

Meehan, D. G., Wang, S., and Chung, D. D. L. (2010). "Electrical-resistance-based sensing of impact damage in carbon fiber reinforced cement-based materials," Journal of Intelligent Material Systems and Structures 21(1), 83-105. DOI: 10.1177/1045389X09354786

Meng, L. Y., Ma, M. G., and Ji, X. X. (2019). "Preparation of lignin-based carbon materials and its application as a sorbent," Materials 12(7), Article ID 1111. DOI: 10.3390/ma12071111

Menini, M., Pesce, P., Pera, F., Barberis, F., Lagazzo, A., Bertola, L., and Pera, P. (2017). "Biological and mechanical characterization of carbon fiber frameworks for dental implant applications," Materials Science \& Engineering C: Materials for Biological Applications 70, 646-655. DOI: 10.1016/j.msec.2016.09.047

Mercader, C., Denis-Lutard, V., Jestin, S., Maugey, M., Derre, A., Zakri, C., and Poulin, P. (2012). "Scalable process for the spinning of PVA-carbon nanotube composite fibers," Journal of Applied Polymer Science 125, E191-E196. DOI: 10.1002/app.36308

Mikkonen, K. S., Kirjoranta, S., Xu, C., Hemming, J., Pranovich, A., Bhattarai, M., Peltonen, L., Kilpelainen, P., Maina, N., and Tenkanen, M., et al. (2019). "Environmentally-compatible alkyd paints stabilized by wood hemicelluloses," Industrial Crops and Products 133, 212-220. DOI: 10.1016/j.indcrop.2019.03.017

Morales, M. S., and Ogale, A. A. (2013). "Wet-spun, photoinitiator-modified polyacrylonitrile precursor fibers: UV-assisted stabilization," Journal of Applied Polymer Science 130(4), 2494-2503. DOI: 10.1002/app.39442 
Moskalyuk, O. A., Tsobkallo, E. S., Yudin, V. E., and Ivan'kova, E. M. (2015). "Influence of the concentration and shape of carbon fillers on the mechanical properties of polypropylene fibers," Fibre Chemistry 46(5), 293-298. DOI: 10.1007/s10692-015-9608-y

Murakami, M., and Ishida, N. (2015). "Development of new synthetic methods based upon carbon-carbon bond activation," Journal of Synthetic Organic Chemistry Japan 73(1), 33-42. DOI: 10.5059/yukigoseikyokaishi.73.29

Nawawi, D. S., Syafii, W., Akiyama, T., and Matsumoto, Y. (2016). "Characteristics of guaiacyl-syringyl lignin in reaction wood in the gymnosperm Gnetum gnemon L.," Holzforschung 70(7), 593-602. DOI: 10.1515/hf-2015-0107

Newcomb, B. A. (2016). "Processing, structure, and properties of carbon fibers," Composites Part A: Applied Science and Manufacturing 91, 262-282. DOI: 10.1016/j.compositesa.2016.10.018

Niu, H., Zhang, J., Xie, Z., Wang, X., and Lin, T. (2011). "Preparation, structure and supercapacitance of bonded carbon nanofiber electrode materials," Carbon 49(7), 2380-2388. DOI: 10.1016/j.carbon.2011.02.005

Otani, S. (1968). "Preparation of fibrous carbon materials," Japan Patent No. 542900.

Paunonen, S., Kamppuri, T., Katajainen, L., Hohenthal, C., Heikkila, P., and Harlin, A. (2019)," Environmental impact of cellulose carbamate fibers from chemically recycled cotton," Journal of Cleaner Production 222, 871-881. DOI:

10.1016/j.jclepro.2019.03.063

Perez, J. M., Rodriguez, F., Alonso, M. V., and Oliet, M. (2011). "Time-temperaturetransformation cure diagrams of phenol-formaldehyde and lignin-phenolformaldehyde novolac resins," Journal of Applied Polymer Science 119(4), 22752282. DOI: 10.1002/app.32866

Poveda, R. L., Achar, S., and Gupta, N. (2012). "Thermal expansion of carbon nanofiberreinforced multiscale polymer composites," JOM 64(10), 1148-1157. DOI: 10.1007/s11837-012-0402-5

Qian, Y., Deng, Y., Qiu, X., Li, H., and Yang, D. (2014). "Formation of uniform colloidal spheres from lignin, a renewable resource recovered from pulping spent liquor," Green Chemistry 16(4), 2156-2163. DOI: 10.1039/C3GC42131G

Qian, Y., Lou, H., Liu, W., Yang, D., Ouyang, X., Li, Y., and Qiu, X. (2018). "Lignin A promising biomass resource," TAPPI Journal 17(3), 125-141.

Ralph, J., Peng, J., Lu, F., Hatfield, R. D., and Helm, R. F. (1999). "Are lignins optically active?," Journal of Agricultural and Food Chemistry 47(8), 2991-2996. DOI: 10.1021/jf9901136

Rhee, I., Kim, J. H., Park, S. H., Lee, S., Ryu, B. R., and Kim, Y. A. (2017). "Mechanical and electrical properties of cement paste incorporated with pitch-based carbon fiber," Carbon Letters 23(1), 22-29. DOI: 10.5714/CL.2017.23.022

Salim, N. V., Blight, S., Creighton, C., Nunna, S., Atkiss, S., and Razal, J. M. (2018). "The role of tension and temperature for efficient carbonization of polyacrylonitrile fibers: Towards low cost carbon fibers," Industrial \& Engineering Chemistry Research 57(12), 4268-4276. DOI: 10.1021/acs.iecr.7b05336

Shioya, T., Akiyama, T., Yokoyama, T., and Matsumoto, Y. (2017). "Formation rate of benzyl cation intermediate from p-hydroxyphenyl, guaiacyl, or syringyl nucleus in acidolysis of lignin," Journal of Wood Chemistry and Technology 37(2), 75-86. DOI: $10.1080 / 02773813.2016 .1235587$ 
Singh, S. K. (2019). "Solubility of lignin and chitin in ionic liquids and their biomedical applications," International Journal of Biological Macromolecules 132, 265-277.

DOI: 10.1016/j.ijbiomac.2019.03.182

Souto, F., Calado, V., and Pereira, Jr., N. (2018). "Lignin-based carbon fiber: A current overview," Materials Research Express 5(7), Article ID 072001. DOI: 10.1088/2053$1591 / \mathrm{aaba00}$

$\mathrm{Su}, \mathrm{C}$. I., and Wang, C. L. (2007). "Optimum manufacturing conditions of activated carbon fiber absorbents. I. Effect of flame retardant reagent concentration," Fibers and Polymers 8(5), 477-481. DOI: 10.1007/BF02875868

Sudo, K., and Shimizu, K. (1992). "A new carbon fiber from lignin," Journal of Applied Polymer Science 44(1), 127-134. DOI: 10.1002/app.1992.070440113

Sudo, K., Shimizu, K., Nakashima, N., and Yokoyama, A. (1993). "A new modification method of exploded lignin for the preparation of a carbon fiber precursor," Journal of Applied Polymer Science 48(8), 1485-1491. DOI: 10.1002/app.1993.070480817

Svinterikos, E., and Zuburtikudis, I. (2016). "Carbon nanofibers from renewable bioresources (lignin) and a recycled commodity polymer [poly(ethylene terephthalate)]," Journal of Applied Polymer Science 133(37), Article ID 43936. DOI: 10.1002/app.43936

Tane, M., Okuda, H., and Tanaka, F. (2019). "Nanocomposite microstructures dominating anisotropic elastic modulus in carbon fibers," Acta Materialia 166, 75-84. DOI: 10.1016/j.actamat.2018.12.029

Tenhaeff, W. E., Rios, O., More, K., Mcguire, M. A. (2014). "Highly robust lithium ion battery anodes from lignin: An abundant, renewable, and low-cost material," Advanced Functional Materials 24(1), 86-94. DOI: 10.1002/adfm.201301420

Teo, W. E., Inai, R., and Ramakrishna, S. (2011). "Technological advances in electrospinning of nanofibers," Science and Technology of Advanced Materials 12(1), 1-19. DOI: $10.1088 / 1468-6996 / 12 / 1 / 11660944$

Terashima, N. (2013). "Diversification of lignin supramolecular structure during the evolution of plants," Mokuzai Gakkaishi 59(2), 65-80. DOI: 10.2488/jwrs.59.65

Tian, D., Shen, F., Yang, G., Deng, S., Long, L., He, J., Zhang, J., Huang, C., and Luo, L. (2019). "Liquid hot water extraction followed by mechanical extrusion as a chemicalfree pretreatment approach for cellulosic ethanol production from rigid hardwood," Fuel 252, 589-597. DOI: 10.1016/j.fuel.2019.04.155

Usmani, S., Aurand, E. R., Medelin, M., Fabbro, A., Scaini, D., Laishram, J., Rosselli, F. B., Ansuini, A., Zoccolan, D., and Scarselli, M., et al. (2016). "3D meshes of carbon nanotubes guide functional reconnection of segregated spinal explants," Science Advances 2(7), Article ID 1600087. DOI: 10.1126/sciadv.1600087

Vicuna, R. (2000). "Ligninolysis: A very peculiar microbial process," Molecular Biotechnology 14(2), 173-176. DOI: 10.1385/MB:14:2:173

Vural, D., Smith, J. C., and Petridis, L. (2018). "Dynamics of the lignin glass transition," Physical Chemistry Chemical Physics 20(31), 20504-20512. DOI: 10.1039/C8CP03144D

Wang, J. Y., Wang, R. Z., and Wang, L. W. (2016a). "Water vapor sorption performance of $\mathrm{ACF}-\mathrm{CaCl}_{2}$ and silica gel- $\mathrm{CaCl}_{2}$ composite adsorbents," Applied Thermal Engineering 100, 893-901. DOI: 10.1016/j.applthermaleng.2016.02.100 
Wang, S., Zhou, Z., Xiang, H., Chen, W., Yin, E., Chang, T., and Zhu, M. (2016b).

"Reinforcement of lignin-based carbon fibers with functionalized carbon nanotubes," Composites Science and Technology 128, 116-122. DOI:

10.1016/j.compscitech.2016.03.018

Wang, X., Wang, Q., Huang, F., and Wei, Q. (2016c). "The morphology of Taylor cone influenced by different coaxial composite nozzle structures," Fibers and Polymers 17(4), 624-629. DOI: 10.1007/s12221-016-5730-6

Yang, H., Zhang, X. H., and Hu, X. (2012). "Carbon fiber frame for military use," Advanced Materials Research 479-481, 488-492. DOI:

10.4028/www.scientific.net/amr.479-481.488

Yang, X., Li, N., Lin, X., Pan, X., and Zhou, Y. (2016). "Selective cleavage of the aryl ether bonds in lignin for depolymerization by acidic lithium bromide molten salt hydrate under mild conditions," Journal of Agricultural and Food Chemistry 64(44), 8379-8387. DOI: 10.1021/acs.jafc.6b03807

Yang, Y., Pan, Y., Feng, Z., and Song, S. (2014). "Evaluation of aerospace carbon fibers," New Carbon Materials 77(3), 1195-1195. DOI: 10.1016/j.carbon.2014.06.036

Yao, Y., Liu, L., Chen, J., Dong, Y., and Liu, A. (2014). "Enhanced oxidation performance of pitch fibers formed from a heterogeneous pitch blend," Carbon 73, 325-332. DOI: 10.1016/j.carbon.2014.02.070

Yu, Q., Zhuang, X., Yuan, Z., Kong, X., Qi, W., Wang, W., Wang, Q., and Tan, X. (2016). "Influence of lignin level on release of hemicellulose-derived sugars in liquid hot water," International Journal of Biological Macromolecules 82, 967-972. DOI: 10.1016/j.ijbiomac.2015.10.045

Yuan, T. Q., Xu, F., and Sun, R. C. (2013). "Role of lignin in a biorefinery: Separation characterization and valorization," Journal of Chemical Technology and Biotechnology 88(3), 346-352. DOI: 10.1002/jctb.3996

Yusof, N., and Ismail, A. F. (2012). "Post spinning and pyrolysis processes of polyacrylonitrile (PAN)-based carbon fiber and activated carbon fiber: A review," Journal of Analytical and Applied Pyrolysis 93, 1-13. DOI:

10.1016/j.jaap.2011.10.001

Zhang, C., Liu, J., Guo, S., Xiao, S., Shen, Z., and Xu, L. (2018). "Comparison of microwave and conventional heating methods for oxidative stabilization of polyacrylonitrile fibers at different holding time and heating rate," Ceramics International 44(12), 14377-14385. DOI: 10.1016/j.ceramint.2018.05.047

Zhang, H., Bai, Y., Yu, B., Liu, X., and Chen, F. (2017). "A practicable process for lignin color reduction: Fractionation of lignin using methanol/water as a solvent," Green Chemistry 19(21), 5152-5162. DOI: 10.1039/C7GC01974B

Zhang, L., Aboagye, A., Kelkar, A., Lai, C., and Fong, H. (2014). "A review: Carbon nanofibers from electrospun polyacrylonitrile and their applications," Journal of Materials Science 49(2), 463-480. DOI: 10.1007/s10853-013-7705-y

Zhang, M., Liu, W., Niu, H., and Wu, D. (2019). "Structure-property relationship of carbon fibers derived from polyimide/polyacrylonitrile blends," High Performance Polymers 31(2), 168-177. DOI: 10.1177/0954008317753872

Zhang, M., and Ogale, A. A. (2014). "Carbon fibers from dry-spinning of acetylated softwood kraft lignin," Carbon 69, 626-629. DOI: 10.1016/j.carbon.2013.12.015

Zhang, M., and Ogale, A. A. (2014). "Carbon fibers derived from acetylated softwood kraft lignin," Polymer Precursor-Derived Carbon 137-152. DOI: 10.1021/bk-20141173.ch006 
Zhou, J., Zhang, H., Deng, J., and Wu, Y. (2016). "High glass-transition temperature acrylate polymers derived from biomasses, syringaldehyde, and vanillin," Macromolecular Chemistry and Physics 217(21), 2402-2408. DOI: 10.1002/macp.201600305

Article submitted: December 10, 2019; Peer review completed: May 24, 2020; Revised version received: June 15, 2020; Accepted: June 16, 2020; Published: June 24, 2020. DOI: $10.15376 /$ biores.15.3.Xu 